A N N A L ES

UNIVERSITATIS MARIAE CURIE-SKŁODOWSKA

LUBLIN - POLONIA

VOL. LXIII, 2

SECTIO G

2016

Uniwersytet Marii Curie-Skłodowskiej w Lublinie

barbara.dudzik@poczta.umcs.lublin.pl

BARBARA DUDZIK

\title{
Generalne klauzule odsyłające w procesie karnym na przykładzie dobra wymiaru sprawiedliwości (uwagi na tle art. 37 k.p.k.)
}

General Clauses in Polish Criminal Procedure

I.

Kodeks postępowania karnego wielokrotnie posługuje się w swoich przepisach generalnymi klauzulami odsyłającymi oraz zwrotami niedookreślonymi. Organy procesowe, prowadząc postępowania karne, muszą bowiem dysponować pewnym marginesem swobody, luzem decyzyjnym. Jednocześnie słusznie zauważa się, iż stosowanie klauzul generalnych w przepisach prawa karnego procesowego nie wywołuje tak dużych wątpliwości, jak w prawie karnym materialnym ${ }^{1}$. Przykładem generalnej klauzuli, która została użyta w kodeksie postępowania karnego, jest „dobro wymiaru sprawiedliwości” (np. art. 37 k.p.k., art. $649 \S 1$ k.p.k., art. $650 \S 1$ k.p.k.). Przepisy kodeksu postępowania karnego zawierają również klauzulę ,interesu wymiaru sprawiedliwości” (np. art. 90 § 3 k.p.k., art. $590 \S 1$ k.p.k., art. $591 \S 1$ k.p.k., art. 607b k.p.k.). W doktrynie wskazuje się, iż „dobro wymiaru sprawiedliwości” oraz „interes wymiaru sprawiedliwości” to zwroty bliskoznaczne, dlatego nie należy czynić dystynkcji pomiędzy nimi²

1 T. Zieliński, Klauzule generalne w procesie karnym, [w:] Zasady procesu karnego wobec wyzwań wspótczesności. Księga ku czci Profesora Stanisława Waltosia, red. J. Czapska, A. Gaberle, A. Światłowski, A. Zoll, Warszawa 2000, s. 786.

2 Ibidem, s. 791. Pogląd ten może budzić uzasadnione wątpliwości w kontekście założenia racjonalności prawodawcy. Skoro w jednym akcie normatywnym użyto różnych pojęć, to w konsekwencji należy uznać, iż mają one odmienne znaczenie. 
II.

Jednym z przepisów kodeksu postępowania karnego, w którym ustawodawca posłużył się pojęciem „dobro wymiaru sprawiedliwości”, jest art. 37 k.p.k. Zgodnie z tym przepisem Sąd Najwyższy może z inicjatywy sądu właściwego przekazać sprawę do rozpoznania innemu sądowi równorzędnemu w oparciu o wskazaną wyżej generalną klauzulę odsyłającą. Instytucja ta przewiduje odstępstwo od ogólnych reguł właściwości sądu i stanowi przykład właściwości z delegacji (z przekazania sprawy).

III.

Rozpoznanie sprawy przez właściwy sąd jest elementem składowym, przewidzianego w art. 45 ust. 1 Konstytucji RP, prawa obywatela do sądu․ Oznacza to, iż strona ma prawo do rozpoznania swojej sprawy nie przez jakikolwiek sąd, ale przez sąd wyznaczony do rozpoznania jego sprawy na mocy ustawy ${ }^{4}$. W piśmiennictwie karnoprocesowym przyjmuje się, że właściwość sądu to upoważnienie do dokonywania przez ten organ określonej czynności procesowej lub określonego zespołu czynności procesowych. Powyższe uprawnienie jest zarazem najczęściej obowiązkiem sądu . Wyróżnić można właściwość ogólną, obejmującą właściwość rzeczową, miejscową i funkcjonalną, oraz właściwość szczególną, w ramach której należy wskazać na właściwość z delegacji, właściwość z łączności spraw karnych i właściwość do wydania wyroku łącznego ${ }^{6}$. W myśl obowiązujących przepisów sąd bada swoją właściwość z urzędu, a w razie stwierdzenia swojej niewłaściwości przekazuje sprawę właściwemu sądowi lub innemu organowi (art. $35 \S 1$ k.p.k.).

Wymieniona powyżej właściwość z delegacji polega na przekazaniu sprawy zawisłej przed sądem właściwym innemu sądowi ze względu na uregulowane w ustawie kryteria ${ }^{7}$. W konsekwencji właściwość z delegacji (z przekazania sprawy) stanowi odstępstwo od reguł właściwości ogólnej sądu. Regulacje procesowe przewidują modyfikacje zarówno w odniesieniu do właściwości miejscowej (art. 36, 37 i 43 k.p.k. oraz art. 11a ustawy z dnia 6 czerwca 1997

3 Zob. szerzej: Z. Kwiatkowski, [w:] System prawa karnego procesowego, t. 5: Sady i inne organy postepowania karnego, red. Z. Kwiatkowski, Warszawa 2015, s. 287-293; M. Zbrojewska, Rola i stanowisko Sądu Najwyższego w procesie karnym, Warszawa 2013, s. 372-373.

4 K. Dudka, [w:] K. Dudka, H. Paluszkiewicz, Postępowanie karne, Warszawa 2015, s. 51.

5 M. Cieślak, Polska procedura karna, Warszawa 1984, s. 238.

$6 \quad$ K. Dudka, op. cit., s. 52. Podkreślić jednak należy, iż poglądy prezentowane przez przedstawicieli doktryny odnośnie do rodzajów właściwości nie są jednolite. Zob. szerzej: W. Jasiński, Bezstronność sądu i jej gwarancje w polskim procesie karnym, Warszawa 2009, s. 185-187.

7 W. Jasiński, Bezstronność sądu ..., s. 187. 
r. - Przepisy wprowadzające Kodeks postępowania karnego), jak również właściwości rzeczowej (art. 25 § 2 k.p.k.). Szczególne znaczenie z perspektywy przedmiotowego artykułu ma właściwość miejscowa, gdyż dobro wymiaru sprawiedliwości stanowi kryterium przekazania sprawy na podstawie art. 37 k.p.k. Właściwość miejscową definiuje się zazwyczaj jako upoważnienie sądu do przeprowadzenia czynności procesowych ze względu na miejsce zdarzenia, które dało podstawę do dokonania tych czynności ${ }^{8}$. Najważniejszym kryterium wyznaczającym właściwość miejscową jest miejsce popełnienia przestępstwa (forum delicti commissi). Zgodnie z art. $31 \S 1$ k.p.k. właściwy miejscowo jest sąd, w okręgu którego popełniono przestępstwo. Jeżeli przestępstwo popełniono w okręgu kilku sądów, to właściwy będzie ten z nich, w okręgu którego wszczęto najpierw postępowanie przygotowawcze (art. $31 \S 3$ k.p.k.). W przypadku, gdyby przestępstwo zostało popełnione na polskim statku wodnym lub powietrznym i nie można byłoby ustalić miejsca popełnienia przestępstwa, to właściwy będzie sąd macierzystego portu statku (art. $31 \S 2$ k.p.k.). W sytuacji, w której niemożliwe byłoby ustalenie miejsca popełnienia przestępstwa, zastosowanie znajdą kryteria pomocnicze wymienione w art. $32 \S 1$ k.p.k. Właściwy miejscowo będzie wówczas sąd, w okręgu którego ujawniono przestępstwo (forum manifestationis), ujęto oskarżonego (forum deprehensionis), oskarżony przed popełnieniem stale mieszkał lub czasowo przebywał (forum domicilii) w zależności od tego, w którym okręgu sądowym najpierw wszczęto postępowanie przygotowawcze (reguła wyprzedzenia) ${ }^{9}$. Jeżeli jednak nie można ustalić właściwości miejscowej na podstawie wskazanych wyżej przepisów, wówczas sprawę rozpozna sąd właściwy dla dzielnicy Sródmieście miasta stołecznego Warszawy (art. $32 \S 3$ k.p.k.). Rozwiązanie to stanowi swoistą „klapę bezpieczeństwa"10, a tym samym wskazuje, jak ważne jest, by w każdym przypadku można było ustalić sąd właściwy miejscowo i by to właśnie on rozpoznawał daną sprawę. Słusznie podkreślił Sąd Najwyższy, iż „zachowanie zasady praworządności wymaga, aby sprawca odpowiadał przed sądem właściwym ze względu na miejsce popełnienia przestępstwa"11. Właściwość z przekazania sprawy (z delegacji) ma zatem charakter nadzwyczajny, gdyż wkracza w obszar procesowych gwarancji praworządności, której warunkiem w państwie prawa jest zasada działania wszystkich jego organów w zakresie swojej właściwo-

8 T. Grzegorczyk, J. Tylman, Polskie postępowanie karne, Warszawa 2011, s. 235; S. Waltoś, Proces karny. Zarys systemu, Warszawa 2009, s. 160.

9 E. Skrętowicz, [w:] R. Kmiecik, E. Skrętowicz, Proces karny. Część ogólna, Warszawa 2009, s. 135.

10 P. Hofmański (red.), E. Sadzik, K. Zgryzek, Kodeks postępowania karnego, t. 1, Warszawa 2011, s. 292.

11 Postanowienie SN z dnia 24 września 1982 r., I KO 69/82, OSNPG 1983, nr 2, poz. 18. 
ści, określonej przepisami prawa ${ }^{12}$. Przestrzeganie ustanowionych przez ustawodawcę reguł ustalania właściwości sądu jest elementem składowym prawa do rzetelnego procesu ${ }^{13}$. Przepisy dotyczące właściwości mają znaczenie nie tylko porządkowe, ale przede wszystkim gwarancyjne. Wyraża się ono w tym, że strony z góry wiedzą, który sąd będzie właściwy do rozpoznania ich sprawy i w konsekwencji pozwala na wykluczenie wszelkich podejrzeń co do manipulacji właściwością miejscową sądu w celu dobrania składu orzekającego odpowiedniego dla stron lub władzy ${ }^{14}$. Nie można również pominąć moralnego aspektu przepisów o właściwości miejscowej, polegającego na tym, iż sprawca przestępstwa powinien odpowiadać tam, gdzie je popełnił ${ }^{15}$.

$\mathrm{Z}$ uwagi na powyższe stosowanie przepisów umożliwiających rozpoznanie sprawy przez inny sąd niż właściwy miejscowo lub rzeczowo (właściwość z delegacji) powinno zdarzać się wyjątkowo. Zarówno doktryna, jak i orzecznictwo jednolicie wypowiadają się w kwestii wyjątkowego charakteru przepisu art. 37 k.p.k. oraz zakazu wykładni rozszerzającej w odniesieniu do niego ${ }^{16}$.

IV.

Przepisy kodeksu postępowania karnego nie zawierają definicji pojęcia „,dobro wymiaru sprawiedliwości” ani chociażby przykładowego wyliczenia okoliczności, których zaistnienie lub brak skutkowałby powstaniem zagrożenia dla tego dobra i w konsekwencji obligowałby Sąd Najwyższy do przekazania sprawy innemu sądowi równorzędnemu. Wynika to z faktu, iż generalna klauzula odsyłająca ze swej istoty jest niedookreślona, nieostra, ma charakter ogólny oraz ocenny. Kryteria stosowania tej klauzuli wiążą się z okolicznościami nie do końca wymiernymi i weryfikowanymi, dlatego nie da się precyzyjnie normatywnie opisać i przewidzieć wszystkich sytuacji, w których znajdzie ona zastosowanie ${ }^{17}$. Jak słusznie się wskazuje, dyskrecjonalność organu procesowego w zakresie decyzji podjętych na podstawie tej przesłanki jest stosunkowo duża, co nie oznacza jednak dowolności ${ }^{18}$.

$\mathrm{W}$ literaturze przedmiotu oraz $\mathrm{w}$ orzecznictwie wielokrotnie podejmowano próby sformułowania definicji „dobra wymiaru sprawiedliwości”, określenia jego

12 Z. Kwiatkowski, op. cit., s. 416; A. Zachuta, Właściwość z delegacji w sprawach karnych (art. 36 k.p.k.), „Prokuratura i Prawo” 2004, nr 2, s. 150.

13 M. Zbrojewska, op. cit., s. 372-372.

14 D. Szumiło-Kulczycka, Prawo do sądu właściwego w polskim procesie karnym i gwarancje jego realizacji, [w:] Zasady procesu karnego wobec wyzwań współczesności ..., s. 248.

15 M. Zbrojewska, op. cit., s. 373; postanowienie SA w Krakowie z dnia 3 lutego 1993 r., II AKo 3/93, KZS 1993, nr 2, poz. 12.

16 Z. Kwiatkowski, op. cit., s. 441 i powołana tam literatura oraz orzecznictwo.

17 Zob. wyrok TK z dnia 15 stycznia 2009 r., K 45/07, OTK ZU 2009/A, nr 1, poz. 3.

18 W. Jasiński, Bezstronność sądu..., s. 215. 
granic znaczeniowych lub chociażby wskazania okoliczności, w następstwie których dochodzi do przekazania sprawy w trybie art. 37 k.p.k. Należy przy tym zwrócić uwagę, że dorobek doktryny i praktyki w tym zakresie jest niezwykle bogaty, co wynika $\mathrm{z}$ faktu, iż przepis ten ma długą tradycję w polskiej procedurze karnej. Już bowiem kodeks postępowania karnego z 1928 r. zawierał przepis umożliwiający Sądowi Najwyższemu przekazanie sprawy innemu sądowi równorzędnemu na wniosek pierwszego prokuratora lub z inicjatywy sądu właściwego, jeżeli ze względu na zabezpieczenie prawidłowego wymiaru sprawiedliwości zachodziła potrzeba wyjęcia sprawy spod rozpoznania sądu miejscowo dla niej właściwego (art. 38 k.p.k. ${ }^{19}$. Wprawdzie sformułowanie „,dobro wymiaru sprawiedliwości” jako kryterium przekazania sprawy przez Sąd Najwyższy innemu sądowi równorzędnemu zostało użyte dopiero w art. 27 k.p.k. z 1969 r. ${ }^{20}$, to jednak nie ulega wątpliwości, że obie przesłanki są do siebie bardzo zbliżone i podobnie je interpretowano ${ }^{21}$.

S. Zabłocki dokonał analizy opublikowanego orzecznictwa Sądu Najwyższego i piśmiennictwa na gruncie przepisów kodeksu postępowania karnego z $1928 \mathrm{r}$. oraz kodeksu postępowania karnego z 1969 r. i zauważył, że pomimo stanowiska Sądu Najwyższego o restryktywnej wykładni klauzuli „dobra wymiaru sprawiedliwości”, z uwagi na wyjątkowy charakter zawierającego ją przepisu, decyzje o przekazaniu sprawy wskazują raczej na jego liberalną interpretację. Autor wyraził pogląd, iż przekazanie sprawy z uwagi na dobro wymiaru sprawiedliwości powinno mieć miejsce wówczas, gdy sprawa dotyczy sędziego sądu właściwego albo osób wykonujących zawody prawnicze w okręgu tego sądu, osób pełniących na jego obszarze właściwości wyższe funkcje publiczne, z wyjątkiem sędziów, gdyż w takim przypadku wystarczająca powinna być instytucja wyłączenia sędziego. Nie powinno natomiast dotyczyć to członków rodziny ławnika, byłego ławnika ani pracownika sądu właściwego. S. Zabłocki konstatuje, że dobro wymiaru sprawiedliwości to również umacnianie autorytetu trzeciej władzy (sądów) i podkreśla, że stosowanie przedmiotowej instytucji powinno być wyważone z uwagi na konieczność przeciwstawienia się przekonaniu o zasadności braku zaufania do sądów, a także braku wiary sędziów i sądów we własny autorytet ${ }^{22}$.

T. Artymiuk, w opracowaniu poświęconym analizie orzecznictwa Sądu Najwyższego dotyczącego art. 37 k.p.k., również zauważył, iż pomimo deklarowanego $\mathrm{w}$ uzasadnieniach orzeczeń poglądu o wyjątkowości tego przepisu,

19 Rozporządzenie Prezydenta Rzeczypospolitej z dnia 19 marca 1928 r. - Kodeks postępowania karnego (tekst pierwotny Dz.U., nr 33, poz. 313).

20 Ustawa z dnia 19 kwietnia 1969 r. - Kodeks postępowania karnego (Dz.U., nr 13, poz. 96 ze zm.).

${ }^{21}$ Zob. szerzej orzecznictwo omówione przez Z. Kwiatkowskiego (op. cit., s. 433-435 oraz powołana tam literatura).

22 S. Zabłocki, Przekazanie sprawy do rozpoznania sądowi równorzędnemu ze względu na dobro wymiaru sprawiedliwości (art. 27 k.p.k.), „Przegląd Sądowy” 1994, nr 7-8, s. 3-36. 
praktyka jego stosowania była nadal bardzo liberalna. W wielu przypadkach zamiast przekazania sprawy sądowi równorzędnemu należało sięgnąć do instytucji wyłączenia sędziego ${ }^{23}$. Jednakże, jak słusznie zauważył L.K. Paprzycki, można zaobserwować zwiększony stopień rygoryzmu, gdyż w wielu sytuacjach kłopotliwych dla orzekających sędziów Sąd Najwyższy stwierdził, iż dobro wymiaru sprawiedliwości wymaga, by to właśnie sąd właściwy podjął się trudu wykazania, że jest bezstronny i obiektywny ${ }^{24}$. Wyniki przeanalizowanego przez T. Artymiuka orzecznictwa Sądu Najwyższego pozwoliły mu na wyodrębnienie kilku grup okoliczności, których zaistnienie świadczyło o tym, iż dobro wymiaru sprawiedliwości wymagało przekazania sprawy sądowi równorzędnemu, innemu niż właściwy: - gdy oskarżonym był: sędzia i były sędzia sądu właściwego, ławnik i były ławnik tego sądu, sędzia sądu nadrzędnego, syn i mąż sędziego sądu właściwego albo nadrzędnego, były sędzia, a potem notariusz w okręgu takiego sądu, oskarżyciel prywatny w innej sprawie - teraz oskarżony o pomówienie sędziego, adwokat w okręgu, a wcześniej aplikant sądowy, biegły często występujący przed sądem właściwym (także brat takiego biegłego), komornik z obszaru właściwości sądu, kurator, a świadkami pracownicy sądu właściwego, syndyk, sędziowie sądu właściwego, burmistrz miasta będącego siedzibą sądu właściwego, pracownik sądu właściwego,

- wpłynęły liczne skargi oskarżyciela prywatnego o stronniczość sądu,

- pokrzywdzonym był: sędzia sądu właściwego albo taki sąd, prokurator, a także żona prokuratora sprawującego urząd na obszarze sądu właściwego albo prokuratury nadrzędnej, funkcjonariusz miejscowej jednostki policji,

- oskarżycielem posiłkowym albo prywatnym był: sędzia sądu właściwego albo nadrzędnego, żona sędziego takiego sądu,

- sprawa o pomówienie sędziów sądu właściwego albo nadrzędnego,

- sprawa o odszkodowanie za działanie sędziów sądu właściwego albo gdy o odszkodowanie występuje oskarżony mający sprawę w sądzie właściwym,

- sprawa dotyczyła nieprawidłowości w sądzie właściwym,

- sprawa dotyczyła przestępstw, jakich mieli się dopuścić sędziowie sądu właściwego albo prokuratorzy z obszaru właściwości takiego sądu ${ }^{25}$.

Z kolei okoliczności wymienione poniżej nie stanowiły, zdaniem Sądu Najwyższego, przesłanki do uznania, iż dobro wymiaru sprawiedliwości wymaga zmiany właściwości miejscowej sądu:

23 T. Artymiuk, Przekazanie sprawy z sądu miejscowo właściwego do innego sądu równorzędnego (art. 37 k.p.k.) w orzecznictwie Sądu Najwyższego, „Studia i Analizy Sądu Najwyższego” 2007, t. 1, s. 141-144.

24 L.K. Paprzycki, Dobro wymiaru sprawiedliwości - art. 37 k.p.k., [w:] Reforma prawa karnego. Propozycje i komentarze. Księga pamiątkowa Profesor Barbary Kunickiej-Michalskiej, red. J. Jakubowska-Hara, C. Nowak, J. Skupiński, Warszawa 2008, s. 396.

25 T. Artymiuk, op. cit., s. 137-138. 
- niewystarczająco wykazany, uniemożliwiający rozpoznanie sprawy w sądzie właściwym, zły stan zdrowia oskarżonego,

- nagłośnienie sprawy w ośrodkach społecznego przekazu,

- wyłącznie subiektywne odczucie stron co do braku bezstronności sądu,

- ekonomia procesowa,

- trudności techniczne rozpoznania sprawy,

- próba zastraszenia sędziego prowadzącego sprawę,

- brak podstaw do ustalenia stronniczości sądu w następujących okolicznościach: oskarżycielem prywatnym była osoba pomawiająca sędziego sądu właściwego o popełnienie przestępstwa; oskarżonym był były sędzia, obecnie adwokat, ławnik z innego wydziału sądu właściwego, prokuratorzy różnych szczebli z obszaru sądu właściwego, funkcjonariusz miejscowej jednostki policji i funkcjonariusz służby więziennej, celnik występujący uprzednio w charakterze oskarżyciela w sądzie właściwym, komornik z obszaru właściwości sądu, adwokat, a także jego żona - wykonujący zawód na takim obszarze, również radca prawny, starosta w mieście siedziby sądu właściwego, burmistrz będący ojcem miejscowego sędziego, syn sędziego sądu właściwego, syn adwokata utrzymujący kontakty towarzyskie z sędziami sądu właściwego, przewodniczący rady powiatu właściwego miejscowo dla sądu, prezydent miasta będącego siedzibą sądu; gdy podejrzewanym był prokurator z obszaru właściwego sądu rejonowego; pokrzywdzonym był: sędzia sądu właściwego albo nadrzędnego, a także brat i żona takiego sędziego, córka miejscowego adwokata, ławnik sądu właściwego - w kolejnej sprawie drugim oskarżonym był pracownik sądu, kurator takiego sądu, prokurator z obszaru właściwego sądu rejonowego; oskarżycielem prywatnym był były pracownik sądu, miejscowy adwokat, a w kolejnej sprawie świadkami byli pracownicy sądu właściwego; świadkiem była sędzia sądu właściwego, pracownik takiego sądu; sprawy o odszkodowanie za niesłuszne skazanie za przestępstwo na szkodę sędziego sądu właściwego; sprawy, w której wyjaśnienia podejrzanego obciążały pracowników sądu; sprawy o pomówienie prokuratora z obszaru właściwości sądu; sprawa, w której pokrzywdzonym był prokurator, zaś żona i córka oskarżonego - miejscowymi adwokatami; sprawa o podrobienie dokumentów w aktach sprawy, a świadkami - pracownicy sądu ${ }^{26}$.

Przeprowadzone przez T. Artymiuka badania empiryczne stały się podstawą do sformułowania wniosku, iż Sąd Najwyższy, oceniając, czy zachodzi przesłanka „dobro wymiaru sprawiedliwości”, bada w istocie, czy istnieje „obawa” lub jej brak „o bezstronność sądu właściwego" ${ }^{27}$. Z kolei fakt, że w niektórych bardzo zbliżonych do siebie, a czasami wręcz identycznych sprawach Sąd Najwyższy

\footnotetext{
26 Ibidem, s. 138-141.

27 Ibidem, s. 136.
} 
orzekał odmiennie, świadczy zdaniem autora o braku czytelnych i ścisłych kryteriów pomocnych $\mathrm{w}$ interpretacji pojęcia „dobro wymiaru sprawiedliwości” w aktualnym wówczas orzecznictwie SN. Jednocześnie autor stwierdza, że wypracowanie zamkniętego kręgu takich kryteriów nie wydaje się możliwe i podkreśla, iż zastosowanie instytucji z art. 37 k.p.k. powinno mieć miejsce w oparciu o indywidualną ocenę SN wszystkich okoliczności konkretnej sprawy. Podsumowując swoje rozważania, autor opowiedział się za wąską wykładnią pojęcia „dobro wymiaru sprawiedliwości” jako określającego wyjątek od reguły ustanowionej w normie konstytucyjnej ${ }^{28}$.

Kolejne rozważania dotyczące treści zawartego w art. 37 k.p.k. sformułowania „dobro wymiaru sprawiedliwości”, w oparciu o przeprowadzone badania empiryczne, przedstawił R.E. Masznicz ${ }^{29}$. Wyróżnił on trzy okoliczności, których zaistnienie umożliwia przekazanie sprawy w tym trybie: wyeliminowanie czynników godzących w niezawisłość lub bezstronność orzekania, usunięcie przeszkody faktycznej w rozpoznaniu sprawy oraz stworzenie warunków swobodnego orzekania. Mając powyższe na względzie, stwierdził, iż ,dobro wymiaru sprawiedliwości" to taki stan, w którym w procesie rzetelnym i jawnym, toczącym się bez nieuzasadnionej zwłoki przed właściwym, niezawisłym i bezstronnym sądem, przy zachowaniu domniemania niewinności oskarżonego i zapewnieniu mu odpowiedniej obrony, całokształt okoliczności towarzyszących stosowaniu norm procesowych sprzyja ustaleniu prawdy oraz wykryciu i pociągnięciu do odpowiedzialności karnej sprawcy przestępstwa, a uchronieniu przed taką odpowiedzialnością osoby niewinnej, a także orzeczeniu środków przewidzianych w prawie karnym, zgodnie z wytycznymi ustawowymi ich stosowania i wymiaru, w celu zwalczania przestępstw i ich zapobieganiu oraz umacnianiu poszanowania prawa i zasad współżycia społecznego, z uwzględnieniem prawnie chronionych interesów pokrzywdzonego ${ }^{30}$. Na tej podstawie autor konkluduje, że jeżeli zachodzi okoliczność uniemożliwiająca osiągnięcie wyżej opisanego stanu i nie może być ona usunięta bez przekazania sprawy innemu sądowi równorzędnemu, to wtedy właśnie możliwe jest zastosowanie instytucji z art. 37 k.p.k. ${ }^{31}$

L.K. Paprzycki uważa, że zasadniczym elementem „dobra wymiaru sprawiedliwości” jest potrzeba zapewnienia przeprowadzenia rzetelnego procesu w rozumieniu tego pojęcia określonym w art. 54 Konstytucji RP, art. 6 EKPCz i kodeksie postępowania karnego. Rzetelny proces karny będzie to taki proces, który zakończy się w rozsądnym terminie, przed obiektywnym i bezstronnym sądem,

\footnotetext{
28 Ibidem, s. 141-144.

29 R.E. Masznicz, Przekazanie sprawy ze względu na dobro wymiaru sprawiedliwości (art. 37 k.p.k.), „Prokuratura i Prawo” 2007, nr 7-8.

30 Ibidem, s. 118.

31 Ibidem.
} 
postrzeganym tak przez bezstronnego obserwatora, będzie prowadzony w warunkach wolnych od negatywnego wpływu na prowadzone w jego ramach czynności, pozwalając realizować prawa uczestników postępowania, w tym przede wszystkim oskarżonego i pokrzywdzonego, co umacnia przekonanie społeczne o samodzielności sądu w rozstrzyganiu sprawy ${ }^{32}$.

W. Jasiński stwierdza, na podstawie orzecznictwa Sądu Najwyższego, iż o zagrożeniu dla „dobra wymiaru sprawiedliwości”, a tym samym o możliwości przekazania sprawy w trybie art. 37 k.p.k., decydują zasadniczo dwie kwestie. Pierwsza z nich to okoliczności, które rodzą uzasadnione podejrzenie co do bezstronności sądu, natomiast druga dotyczy zagrożeń dla rozpoznania sprawy w rozsądnym terminie ${ }^{33}$. Autor trafnie zauważa, że dla dobra wymiaru sprawiedliwości konieczne jest nie tylko zapewnienie bezstronności subiektywnej sądu, ale również zapewnienie zewnętrznych pozorów bezstronności (bezstronności obiektywnej).

V.

Reasumując, należy stwierdzić, że dobro wymiaru sprawiedliwości, o którym mowa w art. 37 k.p.k., jest pojęciem o bardzo szerokich granicach znaczeniowych. W konsekwencji nie jest możliwe skonstruowanie jednej uniwersalnej i precyzyjnej definicji tego sformułowania ani enumeratywne wyliczenie sytuacji, w których dobro wymiaru sprawiedliwości byłoby zagrożone. Nie ma zresztą takiej potrzeby. Zasadne wydaje się jednak wskazanie ogólnych kierunków wykładni tego pojęcia $\mathrm{i}$ tak też się stało w aktualnym orzecznictwie i piśmiennictwie. Przyjęto bowiem, że dobro wymiaru sprawiedliwości wymaga nieustannej dbałości o autorytet przez każdy sąd, zaś cel ten można osiągnąć między innymi przez bezstronne, wnikliwe i sprawne przeprowadzenie postępowania sądowego w każdej sprawie i ukończenie go bez zbędnej zwłoki ${ }^{34}$. Akcentuje się również, że skorzystanie z instytucji przewidzianej w art. 37 k.p.k. jest uzasadnione w sytuacjach, w których realne byłoby naruszenie zasady rzetelnego i uczciwego proce$\mathrm{su}^{35}$. Z kolei ocena, czy w konkretnej sytuacji przesłanka dobra wymiaru sprawiedliwości faktycznie występuje, a tym samym czy jest podstawa do zastosowania art. 37 k.p.k., powinna być dokonywana w oparciu o realia konkretnej sprawy.

32 L.K. Paprzycki, op. cit., s. 404.

33 W. Jasiński, [w:] Kodeks postępowania karnego. Komentarz, red. J. Skorupka, Warszawa 2015, s. 139-140.

34 Postanowienie SN z dnia 18 marca 2005 r., III KO 2/05, OSNKW 2005, nr 1, poz. 592.

35 M. Zbrojewska, op. cit., s. 377. 


\section{BIBLIOGRAFIA}

Artymiuk T., Przekazanie sprawy z sądu miejscowo właściwego do innego sądu równorzędnego (art. 37 k.p.k.) w orzecznictwie Sądu Najwyższego, „Studia i Analizy Sądu Najwyższego” 2007, t. 1.

Cieślak M., Polska procedura karna, Warszawa 1984.

Dudka K., [w:] K. Dudka, H. Paluszkiewicz, Postępowanie karne, Warszawa 2015.

Grzegorczyk T., Tylman J., Polskie postępowanie karne, Warszawa 2011.

Hofmański P. (red.), Sadzik E., Zgryzek K., Kodeks postępowania karnego, t. 1, Warszawa 2011.

Jasiński W., [w:] Kodeks postępowania karnego. Komentarz, red. J. Skorupka, Warszawa 2015.

Jasiński W., Bezstronność sądu i jej gwarancje w polskim procesie karnym, Warszawa 2009.

Kwiatkowski Z., [w:] System prawa karnego procesowego, t. 5: Sady i inne organy postepowania karnego, red. Z. Kwiatkowski, Warszawa 2015.

Masznicz R.E., Przekazanie sprawy ze względu na dobro wymiaru sprawiedliwości (art. 37 k.p.k.), „Prokuratura i Prawo” 2007, nr 7-8.

Paprzycki L., Dobro wymiaru sprawiedliwości - art. 37 k.p.k., [w:] Reforma prawa karnego. Propozycje i komentarze. Ksiega pamiątkowa Profesor Barbary Kunickiej-Michalskiej, red. J. Jakubowska-Hara, C. Nowak, J. Skupiński, Warszawa 2008.

Postanowienie SA w Krakowie z dnia 3 lutego 1993 r., II AKo 3/93, KZS 1993, nr 2, poz. 12.

Postanowienie SN z dnia 24 września 1982 r., I KO 69/82, OSNPG 1983, nr 2, poz. 18.

Postanowienie SN z dnia 18 marca 2005 r., III KO 2/05, OSNKW 2005, nr 1, poz. 592.

Rozporządzenie Prezydenta Rzeczypospolitej z dnia 19 marca 1928 r. - Kodeks postępowania karnego (tekst pierwotny Dz.U., nr 33, poz. 313).

Skrętowicz E., [w:] R. Kmiecik, E. Skrętowicz, Proces karny. Część ogólna, Warszawa 2009.

Szumiło-Kulczycka D., Prawo do sądu właściwego w polskim procesie karnym i gwarancje jego realizacji, [w:] Zasady procesu karnego wobec wyzwań wspótczesności. Księga ku czci Profesora Stanisława Waltosia, red. J. Czapska, A. Gaberle, A. Światłowski, A. Zoll, Warszawa 2000.

Ustawa z dnia 19 kwietnia 1969 r. - Kodeks postępowania karnego (Dz.U., nr 13, poz. 96 ze zm.).

Waltoś S., Proces karny. Zarys systemu, Warszawa 2009.

Wyrok TK z dnia 15 stycznia 2009 r., K 45/07, OTK ZU 2009/A, nr 1, poz. 3.

Zabłocki S., Przekazanie sprawy do rozpoznania sądowi równorzędnemu ze względu na dobro wymiaru sprawiedliwości (art. 27 k.p.k.), „Przegląd Sądowy” 1994, nr 7-8.

Zachuta A., Właściwość z delegacji w sprawach karnych (art. 36 k.p.k.), „Prokuratura i Prawo” 2004, $\mathrm{nr} 2$.

Zbrojewska M., Rola i stanowisko Sądu Najwyższego w procesie karnym, Warszawa 2013.

Zieliński T., Klauzule generalne w procesie karnym, [w:] Zasady procesu karnego wobec wyzwań wspótczesności. Księga ku czci Profesora Stanistawa Waltosia, red. J. Czapska, A. Gaberle, A. Światłowski, A. Zoll, Warszawa 2000.

\section{SUMMARY}

The article is devoted to the issues of general reference clauses in Polish criminal procedure. The discussions presented herein concern one of the clauses, namely "the good of the administration of justice", contained in Art. 37 of the Code of Criminal Procedure. The author states that this term is vague, has very broad boundaries of meaning and, as a consequence, it is not possible to construct one universal and precise definition of that wording or to enumerate the situations in which the good of the administration of justice would be jeopardized. As a matter of fact, there is not such a need. However, it appears to be legitimate to indicate the general directions of the interpretation of this term, and it has been the case in the current judicature and literature. Nevertheless, the determination 
if in a specific situation the precondition of the good of the administration of justice really occurs, and thereby if there are grounds for the application of Art. 37 of the Code of Criminal Procedure, should be made based on the realities of the specific case.

Keywords: the good of the administration of justice; general clauses in criminal procedure

\section{STRESZCZENIE}

Artykuł jest poświęcony problematyce generalnych klauzul odsyłających w polskim procesie karnym. Rozważania w nim przedstawione dotyczą jednej z klauzul, a mianowicie „dobra wymiaru sprawiedliwości”, zawartej w art. 37 k.p.k. Autorka stwierdziła, że jest to pojęcie nieostre, o bardzo szerokich granicach znaczeniowych i w konsekwencji nie jest możliwe skonstruowanie jednej, uniwersalnej i precyzyjnej definicji tego sformułowania ani też enumeratywne wyliczenie sytuacji, w których dobro wymiaru sprawiedliwości byłoby zagrożone. Nie ma zresztą takiej potrzeby. Zasadne wydaje się jednak wskazanie ogólnych kierunków wykładni tego pojęcia i tak też się stało $\mathrm{w}$ aktualnym orzecznictwie i piśmiennictwie. Z kolei ocena, czy w konkretnej sytuacji przesłanka dobra wymiaru sprawiedliwości faktycznie występuje, a tym samym czy jest podstawa do zastosowania art. 37 k.p.k., powinna być dokonana w oparciu o realia konkretnej sprawy.

Słowa kluczowe: klauzule generalne; dobro wymiaru sprawiedliwości; interes wymiaru sprawiedliwości; właściwość sądu karnego 